\title{
The Philosophical Ideas and Themes of Legendary Writers of Indian English Literature through Their Fiction- A Critical Study
}

\author{
Dr. Venkateswarlu Yesapogu, M.A., M.Phil, PhD. Head \\ Dept of English, Principal FAC in V.V. \& M Govt Aided Degree College, \\ Ongole, Prakasam D.T., A.P. India \\ Smt. Manjula Kandula, M.A., M.Ed, M.Phil \\ Principal Priyanka College of Education, Chekoorapadu, \\ Cheerala Road, Ongole, Prakasam D.T. A.P. India
}

\begin{abstract}
Fifty years after India's independence, we are witnessing a new kind of English is finding a voice, a distinctly Indian English, one that is at once global and international, of its culture and of the globe. Presumably, all the Indian writers featured in the issue generally in agreement with the sentiments expressed in favour of appropriating and re-fashioning a new kind of English; certainly, attempts on the part of the erstwhile Empire to re-appropriate its former colonies in the cultural sphere have been met with resistance and criticism.

Writers around the globe, particularly since the twentieth century, the first and second generation writers have wrestled with the equations between ideas and ideologies, and long debated the fraught relationship between political and the literary, if essential sing either is at all possible.

The Indian first and second generation writers have been weighed by the responsibilities, in particularly, of narrating the nation, in all its philosophical ideas by conveying their themes around the centre of philosophy. Their impressive collections of writings, till date, were distinguished a lot to the minds of the then readers up to their imagination and formidable philosophical consciousness, which make them truly international writers.
\end{abstract}

Keywords: Philosophical ideas, contribution, independence, international, twentieth century, around globe. First and second generation writers.

\section{INTRODUCTION}

The history of the writings of the first generation's contribution brought us in to contact with the English Language: during the 150 years of our association with, we have marched to nationhood and Independence and the English language too has during this period waxed in importance, out distanced its prominent status in the counsels of the world.

English is the veritable Suez Canal for intellectual intercourse between the West and the East-between England and India especially; and the traffic is by no means altogether one-sided. Not only Indian thought from Vedic to Modern times has found its way to the West, but eminent Indian thinkers of yesterday and today- from Ram Mohan Roy and Keshub Chandersen to Vivekananda, Tagore, Sri Aurobindo, Gandhi, and Radha Krishnan- have made themselves heard in the West. They have rendered the cultural offensive easier by their mastery of the English language.

Indian writing in English have enlightened the Indian literature with its quality and vividness. Truly, it represented the culture, history, and all the variants necessary for the enrichment of the literature worldwide. And to the fact, India is the third largest producer of the Novels after USA and UK. Although the writings profoundly deal with regionalism, they crossed the natural boundaries with universal themes. India is land of diversity with many languages, religions, races, and cultures. This multiplicity gave the writers an enormous liberty to deal with various themes. The Indian writers dealt with historical, cultural, philosophical, and much more basing their themes around mankind.

\section{The First Generation Writers- And Their Philosophy}

The first generation writers like Raja Ram Mohan Roy, Rabindranath Tagore, and Sri Aurobindo dealt mainly Philosophy in their works. They presented their works for the Western Readers. Because in the 
old books that were written by the travellers and officers of the ruling class it was well maintained that the Englishman initially had an aversion for Indian customs and habits especially those connected with Hinduism. In their view Hindu gods were "absolute monsters of lust, injustice, wickedness, and cruelty", (Wilberforce, in the British parliament, on 22 July 1813) and they considered our religious system as "One grand abomination". So, the first generation writers who were educated in the Western universities wanted to redeem Indian spirituality from the negative perspective of the Westerns. So the literary works, which came out at this juncture of time, projected philosophical approach dealing with the very roots of Hiduism.

Rabindranath Tagore, Sri Aurobindo, and many other writers succeeded in presenting the true spirit and the philosophical views of Hinduism. The profound achievement of the writers of the first generation was also the winning of Noble Prize by Rabindranath Tagore. This has also remarked the achievement of Indian writing and also for wiping away the false attitude of the westerners towards Indian religious system. This helped in enriching the Indian spirituality worldwide.

Raja Ram Mohan Roy: Raja Ram Mohan Roy could be named as the first of Indian masters of English prose. Ram Mohan Roy's interests and inquiries ranged from the rights of women and the freedom of the press to English education, the revenue and judicial systems in India, religious toleration and the plight of the Indian peasantry. He wanted India to become a new and modern country and the Indians to become a virile new people. Not of course, by cutting off our moorings from the past, but by achieving a new integration of our traditional strength with the new scientific disciplines from the West.

Rabindranath Tagore: Rabindranath Tagore is the most outstanding name in the modern Bengal literature. He was the one writer who first brought a significant recognition for modern India in the global literary scenario. The award of the Noble Prize for literature to him was but the beginning of a drama of recognition on a global scale to which there cannot be many parallels in literary history. Tagore's Noble Prize was the result of his doctrine of 'Universal Brotherhood'. Tagore, a philosopher in his own sense, popularised this notion universally which was welcomed all over the world. His notion brought him recognition on the world stage. Tagore wrote primarily in Bengali, but had a mastery of English also. He translated many of his poems and plays into English often changing, telescoping, and transforming the originals. Occasionally he even wrote in the first instance. He was a novelist and short-story writer, and critic of life and literature.

Tagore wrote poetry or poetic drama. Imagination gave him eyes, ears, wings, and a thrilling and melodious voice and poems and plays flowed with amazing rapidity. When the agitation ceased, when the emotional excitement calmed down, he commented on what had passed, speculated and generalized within the Philosophical framework. But at unpredictable moments his poetic iridescent flashes brightened his prose.

Translated by Tagore himself from the original Bangla, the one hundred and three poems in Githanjali (1910) convey impressions of personal religious moods free all dogmatism, free even from ethical overtones. All the poetry is in the feeling and tone, in the prose-poetry, which is simple, fluid, with just enough formal organization to hold a poem together. The imagery is taken from the nature and from Indian classical mythology, especially the Krishna-Radha source. The poems are unified in a search for God.

Sri Aurobindo: Sri Aurobindo is the one incontestably outstanding figure in Indian literature in English. There are people who read Aurobindo seeking an answer to the seeming riddle of his extraordinary career. There are many who see in him the promise of the superman, the profounder of the life divine. There are others who feel attracted to the patriot, the fiery evangelist of Nationalism.

Sri Aurobindo's The Life Divine (1948) is the best of his long prose works. Its dignified and rhythmical prose makes it a significant contribution. The philosophy enshrined here in equally grand.

Savitri (1954) is a vast mystical and philosophical poem closely following the form of the Miltonic epic in XII books. The medium is blank verse, Partly Miltonic, partly Tennyson. It is the reinterpretation of the Savitri-Satyavan legend from Mahabharatha. Savitri here is the power of true love allied to Satyavan who is truth. Together they conquer death. The interpretation makes Savitri, in a way, a poetic version of The Life Divine, since the rise of mind of the super mind requires the defeat of death. 


\section{The Philosophy AND Contribution OF SECOND Generation Writers}

The British rule had its high impact on the second-generation writers. Disillusioned by the failure of the British rulers to ameliorate the plight of the suffering Indians, there grew an atmosphere of earthy realism. Literature became a convenient tool to dramatise and popularize the national cause. The emergence of second generation's Indian English Literature, especially novel, of social realism and revolution after World War I can be seen both as an Indian phenomenon and as a part of the English social realism of the period. The freedom struggle caught the imagination of the entire nation, no less the Indian English writers. No significant writer could escape the impact of the mighty movement sweeping the country.

The novelists who made a mark in the period included Mulk Raj Anand, Raja Rao and R.K.Narayan. Anand's Untouchable (1935), Coolie (1936) and Two Leaves and a Bud (1937) brought him to the forefront as a socially committed novelist. He not only highlighted the colonial exploitation of Indians but also the caste and class oriented exploitation of the untouchables and the poor within Indian society.

Raja Rao: Raja Rao's Kanthapura (1938) remain a milestone in its projection of the Gandhian phenomenon and the vast chunk of humanity was aroused socially and politically by it. The novels dealing with the freedom struggle gave vivid pictures of the exploitation and the arrogance of the foreign rulers, as also the portrayal of an awakened people struggling for their birthright. The growth of the historical novel coincided with the intensification of the struggle for Indian freedom, especially after First World War. The focus of these novels has been shifted from religious aestheticism to the contemporary socio political concern.

Indeed it is the English who brought with them the enlightenment of the West and inspired the Indians to imbibe the spirit of nationalism. In the early decades of the century, the English system had nearly succeeded in giving the people a unity in law, in public administration; in finance and in education that was hitherto unknown to them and ironically this has resulted in generating a sense of national unity which urged them to fight for freedom in the later stages. The intellectuals, be they philosophers, historians or literary artists, have traditionally played significant roles in national revolutions of the world. They reached the minds of the people through their writings and subjected every institution of the society to a specific political philosophy to propagate through philosophical and nationalism point of view.

Ramaswamy, the protagonist in the novel The Serpent and the Rope is a South Indian Brahmin that hails from an orthodox family and he is a descendent of a medieval Vedantin. He is a research scholar in France, married to a French intellectual, Madeleine. Their first child dies of a lung complication and the shadow of death affects Rama no less than Madeleine. He feels at home only with his step mother and step sister in India, deriving from them the rapture of immortality. The relationship between Madeleine and Ramaswamy does not endure. Madeline as a wife in the spirit of " Sahadharmacharini" does not fit into the value system of Ramaswamy and in reality their marriage is a failure, if not a disaster. Madeleine represents the materialism of the West and Ramaswamy symbolizes the spiritualism of the East which are locked in a tough contest.The expatriate Ramaswamy conscious of his privileged position as a brahmin in the Hindu social hierarchy constantly aspires to realize the full metaphysical connotations of true brahmin- hood for " a Brahman is he who knows Brahman ". With that his quest starts and ends. The expatriate is a pilgrim of eternity and his identity has been split between the two opposite factors of Time and Eternity, of History and Tradition, the formar always representing to him the modern Western existence and the latter the Indian Ethos.

Mulk Raj Anand: Anand's contribution to the making of the Indian English has a special significance as works of protest literature. Anand's upbringing during his childhood days in the context of British Colonial India gave him the advantage of first hand observation of several kinds of oppression and exploitation in India. Sociological-imagination stands as the backbone of the Anand's artistic achievement. Anand was a committed artist with a philosophical world-view and a moral and poetic vision of life. The image of Indian society in all its ramifications is the focal point of his creative imagination. As a social realist and critic, he lampooned injustice of every dimension. Mulk Raj Anand and R.K.Narayan have managed to hold on to choose a course and each has now to his credit a corpus of creative fiction of sufficient bulk and quality to merit for their serious study. 
R.K. Narayan: R.K. Narayan, a creative artist in fiction for over four decades, draws his strength from an inexhaustible source - Indianness. He is the most essentially and comprehensively Indian of the Indo Anglian novelists." Narayan's novels have a strong story line and his characters are clearly delineated. Placed in situations which are well developed in the novels, they exhibit a wide range of feelings through which it is not difficult to identify the main emotion. The traditional method of storytelling that Narayan follows in his fiction makes his novels more Indian than Western, though the novel itself is a Western form of literature, in that like all Indian stories it has a beginning, a middle and an end. Of course, his characters are not idealized, but one can still find in them the interplay of emotions out of which the predominant emotions could be identified and worked out.

But while analyzing Narayan's novels from the Rasa point of view the traditional method of working out only the friendly emotions has been followed. But as the traditional theory permits an alignment of inimical Rasas through the intervention of a catalytic emotion, like, for example, the emotion of the Wonderful (Adbhuta). The analysis has taken recourse to the traditional theory of reconciling the opposites (Virudha) through an intermediary emotion. Without deviating very much from the traditional mode, and by sticking to it by and large Narayan's novels have been analyzed from the Rasa point of view.

One of the principles by which the true Erotic emotion is to be distinguished from the shadowy is that if the woman desired by man is somebody else's wife, the love of that man for that woman is not true Srngara but the simulacrum of love sentiment. Another instance is where the love is not reciprocated and the third where the love is for a lowly woman. In The Guide Raju loves Rosie who; is a dancing girl, who does not reciprocate his love and who is Marco's wife. As pointed out earlier the shadowy love emotion which can all be traced in Raju's desire for Rosie.

As a self styled guide Raju has been guiding people to the tourist spots in Malgudi. It is his blood to be a guide wherever he is and in whatever he does. So his affair with Rosie though one sided marks another side of his guiding disposition. At a time when she is drifting without a proper sense of direction to exhibit her talent as a dancer, Raju enters her life as her lover and starts guiding her form out of a moribund existence to a thrilling life of glare, publicity and renown. The instinct to guide others is an instinct for self - effacement, putting the others above oneself. By his own confession towards the end of the novel there is something of a Karma Yogi in Raju. This dormant emotion surfaces slowly and gets manifest when by a quirk of fate Raju is thrown into jail. Even the act of forgery which lands him in jail is done with a view to preserving Rosie nee Nalini for art so that Marco may not again consign her into oblivion. Once he has all the time to himself to ruminate over his life, the latent yogic instinct in him starts asserting itself. But it requires greater impetus to manifest itself completely and this final push forward is supplied by the saintliness thrust upon him by the people of Mangala. The factors that contribute to the generation of the Quiet emotion are worked out sometimes through hints and sometimes directly by Narayan in the last few pages of the Novel. In fact there is more of suggestion (dhvani) than statement (vacya) in the words and actions of Raju on the twelfth day of his fasting, culminating in the excellent suggestion of his final action, the body is sagging and the spirit soaring.

And there is an uneasy fluctuation in the love between Sriram and Bharati in Waiting for the Mahatma. In both, there is separation followed by union. But while in there is The English Teacher there is pattern of union, separation and reunion, in Waiting for the Mahatma separation predominates over union in the first part of the novel and the actual union with Bharati totally participation in it comes towards the end of the novel and even there it is only hinted at. The uneasiness of Sriram in not being able to find the exact response that he is looking for in Bharati makes for an interesting situation of separation (Vipralamba). It takes a considerable amount of time for Sriram to know that Bharati is responding to his love and even than he is not quite sure that he will receive encouragement from her. This ding-dong battles between his desires and the fulfillment being postponed makes Sriram a typical lover in separation. The majority of the forms of separation as per the Indian traditional theory like separation desiring union (Abhilasha Vipralamba), caused by exile (Pravasa Vipralamba) and by curse (Sapa Vipralamba) can be observed in Sriram's fluctuating fortunes.

The love of Bharati for India is greater than her love for Sriram. Normally there should have been a conflict in her mind between these two alternatives. But in the novel there is no such clash because for Bharati love for Sriram can come only after her love of India is fulfilled. That necessitates the introduction of a character who can embody that principle of the Nation. Hence the presence of 
Mahatma Gandhi. Once Gandhi is introduced as a character in the novel, not marginally by centrally important to the theme, it becomes necessary for a critic to trace the emotion embodied in the Mahatma. But Narayan has not made of Gandhi, either. As a matter of fact Gandhiji as a a character mixes unobtrusively into the plot of the novel not as a fictional character but as one who is known to all of his contemporaries in real life.

In Waiting for The Mahatma, we get absorbed in the situation. We see Sriram hearing Gandhiji's speech:

'But', Mahatmaji was saying, "If I have

the slightest suspicion that your heart

is not pure or that there is no bitterness

there, I'd rather have the British

stay on. It's the lesser of two evils."

"Sriram thought, 'Oh revered Mahatmaji,

have no doubt my heart is pure and without

bitterness. How can I have any bitterness

in my heart for a creature who looks

so divine?"(p.20)

Here the emotional experience of the character is so different from the reader that the reader knows what Gandhiji is talking about and when he sees Sriram's misinterpretations of Gandhi's speech, he experiences the Sthayin Hasa, whereas the naïve Sriram experiences a kind of Rati. It is the technique of R.K. Narayan to let the reader get better of the hero. So as for Abhinavagupta would be a better suitable term for the novels of R.K. Narayan.

In The English Teacher the translation form the comic to the Erotic has been excellently worked out by Narayan. Krishnan's bachelor life offers a great deal of scope for comic situations. The traditional Comic sentiment is a coin, admitting of two kinds of humour, one aimed at one's own self (Atmasta), and the other ridiculing the others (Parasta). Krishnan's comments on his won job as an English teacher and his awkwardness while looking for a house belong to the first variety. His remarks on Gajapathy, the house owners, the houses he inspects to fix up one for himself and the unhygienic and insufficient condition of the Hostel Bathrooms are the second type of humour.

His Swami and Friends (1935) struck a totally different note, catching bemusedly the slow pace of life in Malgudi, a fictional microcosm of India. His other important works are The Bachelor of Arts (1937) and The Dark Room (1938) placed him as a comic ironist.

In The Dark Room, the proud heroine, Savitri, having discovered her husband's infidelity, sulks and goes to 'the dark room', i.e., 'kopbhavan'. Eventually she abandons her husband and children. But tormented by memories of her family, she returns submitting herself to obligations. Despite protagonist's 'resignation', the novel carries the ironical social comedy. As the second generation writers like with Mulk Raj Anand, R.K. Narayan and Raja Rao make them a remarkable triad, affiliated in the choices of themes and with his enchanting prose style. He too is a product of Gandhian age, and reveals in his work his sensitive awareness of the forces let loose by Gandhian revolution as also of the thwarting or steadying pulls of past tradition.

Raja Rao's first novel Kanthapura presents life seen through a believer's perspective. India is portrayed like Sita in the toils of the Ravana. Gandhi as avatar of Vishnu - save India from the 'Redmen'. Moorthy is the local hero, a Gandhian leader. All political education is conveyed through the Harikath Man, Jayaramchar, who retells the Rama epic equating it with Gandhi's struggle for Swaraj. The narrator is an old woman, given to gossiping and breathless narration of whatever comes to her tradition-steeped mind. 


\section{CONCLUSION}

Indian Writers in English have made the most significant contribution in the field of the English novel. Indian novel has grown considerably in bulk variety, and maturity. The development of Indian novel follows certain definite patterns, and it is not difficult to trace its gradual progression from the imitative stage to the realistic to the Psychological to the experimental stage. In the growth and development of Indian English novel, the 1980s occupy a unique position. During this period, some very promising novelists published their first works. Some old masters also came out with works, which show that their creative powers have been intact all along. It is during the eighties that Indian novelists earned unheard of honours and distinctions not only in India but also in abroad. The works by these novelists, like the first and second generation novelists, speak eloquently about their originality and unprecedented inventiveness.

Indian English literature is now a reality, which cannot be ignored. During the recent decades, it has attracted a widespread interest both in India and abroad. What began as a "hot-house plant" has now attained a luxuriant growth, branching off in several directions. The Indian writers have made the most remarkable contribution to the sphere of fiction, which as Mulk Raj Anand says, has "come to stay as part of world literature." An idea of the true potential of this form of literature in India can be had by comparing the early novels by Indians with the recent arrivals in the same field of literary creation.

However, Indian writing in English in the Contemporary literary Scenario enjoys equal status with the literatures of the other Countries. Indian writers have made their voice heard around the World in the Indian way, expressing too artistically. Moreover, Indian Writers in English too in the past times have managed to excel in all areas of literature and achieved global recognition.

The first and second generation's Indian writings in English have enlightened the literature with its quality and vividness. Truly, it represented the culture, history, and all the variants necessary for the enrichment of the literature worldwide. In fact, India is the third largest producer of the novels after USA and UK. Although the writings profoundly deal with regionalism, they crossed the natural boundaries with universal themes. India is the land of diversity with so many languages, religions, races, and cultures. This multiplicity gave the writers an enormous liberty to deal with various themes. These third generation Indian writers also dealt with historical, cultural, philosophical and much more basing their themes around mankind. The first and second generation writers have concentrated their themes around sociological, Diasporic elements, feminine subjects, science and technologies, explorative writings, and much more.

India has significantly contributed to the overall world literature. This contribution of India has been chiefly through the Indian writing in English, novelists being in the forefront in this respect. A number of novelists on the contemporary scene have given expression to their creative urge in no other language than English and have brought credit to the Indian English fiction as a distinctive force in the world fiction. To attempt creative expression on a national scale in an alien medium has seldom happened in human history, and it speaks of the prolific quality of the Indian mind to assimilate the newly confronting situations and the complex dilemmas of modern World. The new English fiction exhibits confidence in tackling new themes and experiments with new techniques and approaches to handle these themes. The novelists come to their task without any preconceived notions of what constitutes literary content. This encourages them to focus on a vast and comprehensive canvas and to invest their themes with epic dimensions.

As far as Indian literature is concerned, it has perhaps been easier for these first and second generation novelists to reflect the new challenges and changes because of the simple fact that its vehicle itself is a globalised language. Again, the writers of the new fiction have mostly been a part of the Indian diaspora. Living in the west, and using English almost like a mother tongue, they have been thoroughly exposed to significant modern western literary movements like Post-Modernism, and to various narrative techniques like magic realism. This has enabled them to give a fresh orientation to fiction. At the same time, the best of them continue to have strong roots in India, so that they remain true to the kindred points of India and the west.

It is significant that the spirit of the age is more pervasively and effectively reflected in the first and second generation fiction than in other forms like poetry and drama. The novel, by its very nature, is better equipped to deal with social reality, whatever, liberties it may take in projecting it. It is hardly surprising therefore that the most substantial contribution of the period comes from the first and second generation fiction. 
The Philosophical Ideas and Themes of Legendary Writers of Indian English Literature through Their Fiction- A Critical Study

\section{REFERENCES}

Anand, Mulk Raj. Coolie. London : Penguin. 1936 Print.

Anand, Mulk Raj. Two Leaves and a Bud. London: Penguin,, 1937 Print.

Anand, Mulk Raj. Untouchable. London: Penguin. 1940 Print.

Anderson, Benedict. Imagined Communities : Reflections on the origins and spread of Nationalism. London: Verso.

Asnani, Shyam. New Dimensions of Indian English Novel. Delhi: Doaba House, 1987 Print.

Aurobindo. Savitri. Sri Aurobindo Ashram, Pondicherry, 1954 Print.

Aurobindo. The Life Divine. Sri Aurobindo Ashram Pondicherry, 1948 Print.

Carr, E.H. What is History? U.K. : Penguin books.

Iyangar Srinivas, K.R. Indian Writing in English. New York: Asia Pub. House. 1973 Print.

Naik, M.K. A History of Indian English Literature. New Delhi: Sahitya Akademi. 1982 Print.

Narayan. R.K. Swami and Friends, Bombay: Oxford University Press. 1935 Print.

Narayan. R.K. The Bachelor of Arts. Bombay: Oxford University Press 1937 Print.

Narayan. R.K. The Dark Room. Bombay: Oxford University Press 1938 Print.

Narayan. R.K. The English Teacher. Bombay: Oxford University Press 1938 Print.

Narayan. R.K. Waiting for the Mahatma. Bombay: Oxford University Press 1958 Print.

Narayan. R.K. The Guide. Bombay: Oxford University Press 1940 Print.

Rao, Raja. Kanthapura. Bombay: Oxford University Press. 1938 Print.

“ " The Serpent and the Rope. London: John Murray, 1960 Print.

“ " The Policeman and the Rose. New Delhi: Oxford university Press, 1978 Print.

Tagore, Rabindranath. Gitanjali. New Delhi: Oxford university Press, 1910 Print.

\section{AUTHORS' BIOGRAPHY}

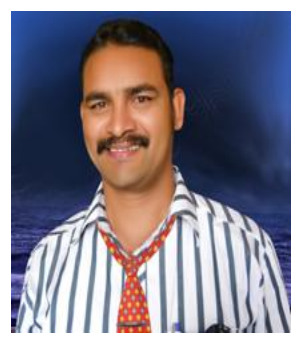

Dr.Venkateswarlu Yesapogu, awarded his $\mathrm{PhD}$ degree in (2012) in the contemporary Indian fiction at the Acharya Nagarjuna University, GUNTUR, Andhra Pradesh, India, his M.A., M.Phil, also happened in the English literature. He is now teaching English Literature and Phonetics in V.V. \&M. Degree College ONGOLE. He became the youngest Principal FAC by virtue of awarded $\mathrm{PhD}$ and seniority among existing staff since 2009. His teaching is on main research interests including teaching of Phonetic Science as well as communication skills. He has recently published two books. The first entitled “The Fictional World of Amitav Ghosh" with ISBN 9789382186397; and published several other articles in reputed international journals. $\mathrm{He}$ has participated National and International seminars/conferences.

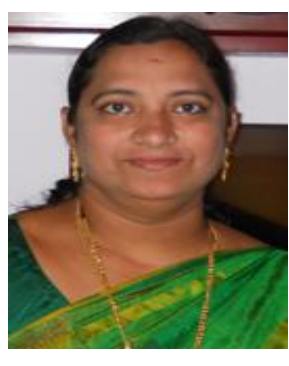

Smt. Manjula Kandula, who is the present Principal of Priyanka college of Education, Chekoorapadu, Cheerala road, ONGOLE, PRAKASAM D.T. A.P. INDIA. She did her M.A. Litt, in English Literature. And also she completed M.Ed in Education in Acharya Nagarjuna University Guntur A.P. India. Moreover, She also awarded her M.Phil in Education from M.K.University, Madurai, T.N. India. Right now she is also working as an Assistant Proferssor in A.N.U. P.G. Centre Campus, ONGOLE, Prakasam D.T., A.P., India, as a guest faculty. 